\title{
GESTOS DIDÁTICOS REVELADOS NO DIZER DO PROFESSOR DE LÍNGUA PORTUGUESA EM SITUAÇÃO DE ENSINO DE ESCRITA
}

\author{
Danielly Dayane Soares de Macedo * \\ Maria de Fátima Alves ** \\ Roziane Marinho Ribeiro ${ }^{* * *}$
}

RESUMO: Neste artigo, apresentamos um estudo de caso (MINAYO, 1994) cujo objetivo consiste em identificar e interpretar os gestos didáticos evidenciados no dizer de um professor de Língua Portuguesa durante intervenções que visavam direcionar os alunos à produção escrita do gênero textual conto fantástico. Para tanto, apoiamo-nos nas discussões propostas pelo Interacionismo Sociodiscursivo, no que se refere às condições de produção de texto e nas marcas enunciativas asseveradas por Bronckart (1999). Em seguida, pautando-nos nos pressupostos da Didática das Línguas, discorremos acerca da noção de gestos didáticos. Nesse sentido, trata-se de uma pesquisa pautada no paradigma qualitativo de ciência (MINAYO, 2009), de base etnográfica (MATTOS, 2011). A geração dos dados ocorreu em duas etapas: (1) entrevista semiestruturada; (2) filmagem de uma aula ministrada pelo participante, em uma turma do terceiro ano do ensino médio, vinculada a uma Escola Cidadã Integral situada na cidade de Campina Grande - PB. A partir deste estudo, observamos que, durante a aula em questão, o professor acionou os gestos de criação de memória didática (interna e externa), regulação, implementação do dispositivo didático, institucionalização e formulação de tarefas; os quais se desdobraram em gestos didáticos específicos. Esses gestos sinalizam o gerenciamento realizado pelo professor no tocante às orientações para a produção escrita do conto, tendo em vista o contexto de interação no qual está inserido.

PALAVRAS-CHAVE: Ensino de escrita; Gestos didáticos; Orientações para produção de textos.

\section{Introdução}

É por meio da mediação docente que os objetos de ensino previstos nos currículos, bem como em outros documentos parametrizadores do trabalho docente, se transformam em objetos ensinados (SCHNEUWLY, 2009 apud GOMES-SANTOS; JORDÃO, 2017).

\footnotetext{
* Mestranda em Linguagem e Ensino pela Universidade Federal de Campina Grande (UFCG).

** Doutora em Linguística pela Universidade Federal de Pernambuco (UFPE). Professora adjunta da Unidade Acadêmica de Educação e do Programa de Pós-Graduação em Linguagem e Ensino da Universidade Federal de Campina Grande (UFCG).

*** Doutora em Linguística pela Universidade Federal da Paraíba (UFPB). Professora adjunta da Unidade Acadêmica de Educação e do Programa de Pós-Graduação em Educação da Universidade Federal de Campina Grande (UFCG). Realizou estágio de pós-doutoramento na Universidade Nova de Lisboa (UNL).
} 
Gomes-Santos e Jordão (2017) afirmam que "o trabalho de ensino tem como objeto os processos psíquicos dos alunos, ou seja, seus modos de pensar, fazer e falar" (GOMESSANTOS; JORDÃO, 2017, p. 62), transformados por meio de sistemas semióticos utilizados pelos docentes, o que apresenta como resultado esses mesmos modos transformados.

Corroborando as afirmações de Dolz, em entrevista realizada por Silva e Silva (2012), para o qual a noção de gestos profissionais consiste em formas características das intervenções docentes em seu trabalho (SILVA; SILVA, 2012), assumimos que analisar o trabalho docente sob o viés dos gestos profissionais pode contribuir para a caracterização, interpretação e, consequentemente, para a compreensão do trabalho do professor. Nessa perspectiva, compreendemos que o ensino não ocorre de maneira mecânica, ou seja, é uma atividade situada e, portanto, as especificidades ligadas a um determinado contexto de ensino também são decisivas para o desenvolvimento das ações do professor.

Nesse sentido, considerando o trabalho realizado pelo professor ao longo das suas aulas, estruturamos a seguinte pergunta investigativa: (1) Que gestos didáticos são mobilizados por um professor de Língua Portuguesa durante intervenções que visam direcionar o aluno à produção escrita do gênero textual conto fantástico?

No intuito de respondê-la, traçamos como objetivo geral: Analisar os gestos didáticos acionados em intervenções docentes que visam direcionar os alunos à produção de gêneros textuais em turmas do ensino médio. Já como objetivos específicos, delimitamos: (1) identificar os gestos didáticos acionados na situação de interação em questão; (2) interpretar os gestos didáticos identificados, à luz de pressupostos advindos do Interacionismo Sociodiscursivo.

Para tanto, fundamentando-nos, inicialmente, na Didática das Línguas, discorreremos acerca das noções de gestos didáticos fundadores e específicos; conforme os estudos de Messias e Dolz-Mestre (2015), SCHNEUWLY (2000 apud NASCIMENTO 2011), SCHNEUWLY (2009 apud GOMES-SANTOS; JORDÃO, 2017) e AEBY-DAGHÉ; DOLZ (2007 apud GOMES-SANTOS; JORDÃO, 2017). Em seguida, trataremos da base de orientação para produção de textos e das marcas enunciativas propostas pelo Interacionismo Sociodiscursivo, com base nos pressupostos asseverados por Bronckart (1999, 
2006); Machado e Bronckart (2009) e Silva (2013). Tais fundamentos precedem, respectivamente, os procedimentos metodológicos, a análise dos dados e as considerações às quais chegamos a partir deste estudo.

\section{Gestos didáticos fundadores e específicos}

Através de gestos que apresentam significados que os aprendizes compreendem e acompanham, o professor deve tornar presentes (gesto de presentificação) os objetos de ensino e, em reciprocidade a isso, delimitar (gesto de elementarização/delimitação) as dimensões ou tópicos a serem tratados como objetos de estudo (SCHNEUWLY, 2000 apud NASCIMENTO 2011; SCHNEUWLY, 2009 apud GOMES-SANTOS; JORDÃO, 2017). Esses gestos, segundo Silva (2013), servem como base para os demais gestos que envolvem o agir dos professores no que se refere à prática didática. Nessa perspectiva, a mediação docente pode ser observada a partir de uma dupla semiotização.

Gomes-Santos e Jordão (2017), retomando as afirmações de Schneuwly (2009), salientam que o trabalho docente engloba "o uso de instrumentos didáticos” (GOMES-SANTOS; JORDÃO, 2017, p. 63), um conjunto de elementos que permitem a transformação da interação didática. A exemplo disso, tem-se "tanto as fichas, quanto os comandos das atividades, os meios de expor, a linguagem e a gestualidade; todo dispositivo material que atua, em um dado momento, quando se está em um contexto didático" (SCHNEUWLY, 2009, p. 32 apud GOMES-SANTOS; JORDÃO, 2017, p. 63).

Ainda no que se refere a esses instrumentos, Gomes-Santos e Jordão (2017) destacam que Schneuwly (2009) estabelece três categorias que os distinguem entre si: a primeira compreende instrumentos constitutivos do ambiente institucional e os instrumentos de ordem material (livros didáticos, cadernos, lousa, textos xerocopiados, data show, entre outros materiais); a segunda e a terceira categorias compreendem o funcionamento das disciplinas escolares. Essas últimas, segundo os autores, tratam de instrumentos que permitem a implementação dos gestos didáticos de presentificação e de delimitação.

Cabe ao professor gerenciar esse conjunto de instrumentos tendo em vista o objeto ensinado. Esse gerenciamento ocorre através de um conjunto de gestos acionados pelo 
docente, os quais materializam a intencionalidade didática; desse modo, são chamados de gestos didáticos (AEBY-DAGHÉ; DOLZ, 2007 apud GOMES-SANTOS; JORDÃO, 2017). Esses gestos consistem, portanto, em importantes recursos para que o professor efetive o seu trabalho, conduzindo os alunos durante o processo de ensino.

Messias e Dolz-Mestre (2015) explicam que os pesquisadores do Groupe de recherche pour l'analyse du français enseigné (GRAFE), preocupados com o trabalho dos docentes de Língua Francesa (enquanto primeira língua), postularam a existência de gestos fundamentais "que se integram ao sistema social complexo da atividade docente e que são regidos por regras e códigos convencionais, estabilizados pelas práticas, já secularizadas, da cultura escolar" (MESSIAS; DOLZ-MESTRE, 2015, p. 52). Esses gestos consistem, de forma mais ampla, em gestos linguageiros aos quais também e associam gestos não linguageiros (SCHNEUWLY, 2009 apud SILVA; DOLZ-MESTRE, 2015). Os autores destacam, ainda, que ao considerar a noção de gestos didáticos fundadores em relação ao trabalho docente supõe-se uma "preocupação que recai sobre o plano da transposição didática interna" (SILVA; DOLZ-MESTRE, 2015, p. 52). Tal afirmação retoma, assim, a acepção do trabalho docente vinculado às especificidades de contextos específicos de ensino.

Messias e Dolz-Mestre (2015) explicam que Aeby-Dagnhé e Dolz (2008) postulam a existência de sete gestos didáticos fundamentais, os quais podem, de acordo com as intervenções desenvolvidas pelos professores, gerar diferentes gestos específicos. Quais sejam: gestos de presentificação, de focalização ou elementarização, formulação das tarefas, implementação do dispositivo didático, criação de memória didática, regulação e de institucionalização.

Retomando os estudos de Schneuwly (2009), Gomes-Santos e Jordão (2017) apresentam a seguinte categorização, referente aos gestos didáticos fundamentais.

Implementação do dispositivo didático: Implica mobilização de uma série de meios e de recursos para a instanciação do contexto (milieu) de ensino e para a criação das condições de ingresso do aluno na atividade escolar proposta; 
Regulação: Implica tomada de informações e interpretação dos efeitos da implementação dos dispositivos didáticos, com base na avaliação dos obstáculos e dos aportes (saberes apropriados) dos alunos no processo de construção do objeto;

Institucionalização: Implica a fixação de maneira explícita e convencional do estatuto cognitivo de um saber para construir a aprendizagem, permitindo ao aluno utilizar este saber em circunstâncias novas e garantindo ao professor a possibilidade de exigi-lo como saber oficial, comum à turma [...];

Criação de memória didática: Implica a reconstituição, em uma matriz integral, dos diferentes elementos em que o objeto de ensino foi decomposto. Trata-se, assim, de um gesto transversal aos demais gestos e à sequência de ensino, uma vez que busca reestabelecer a totalidade do objeto, fragmentada pelo trabalho de ensino. (SCHNEUWLY, 2009, p. 37-41 apud GOMES-SANTOS; JORDÃO, 2017, p. 65-66)

Além desses gestos, Nascimento e Brun (2017) apresentam o gesto de formulação de tarefas, retomando os estudos de Aeby Dagné e Dolz (2008), o qual inter-relaciona o objeto ao dispositivo didático (AEBY DAGNÉ, 2008 apud NASCIMENTO; BRUN, 2017). Segundo os autores, é por meio desse gesto que os professores apresentam consignas a partir das quais o objeto de ensino é presentificado.

Dito isto, discorreremos, a seguir, acerca dos pressupostos advindos do Interacionismo Sociodiscursivo que contribuirão para a interpretação dos gestos didáticos acionados pelo professor participante.

\section{Base de orientação para produção de texto de acordo com o Interacionismo Socio-} discursivo

$\mathrm{Na}$ perspectiva do Interacionismo Sociodiscursivo, a elaboração e desenvolvimento dos conhecimentos humanos ocorrem através das "atividades coletivas concretas" (BRONCKAR'T, 2006, p. 186). Ou seja, nas relações de interação do sujeito com o mundo; as quais, segundo Bronckart (2006), são delineadas sob o viés das dimensões social e histórica, e mediadas pela linguagem.

Segundo Bronckart (1999), uma vez que o agente mobiliza representações particulares acerca dos mundos formais, construindo uma situação de ação de linguagem interna, é essa situação interiorizada que influenciará a produção do texto. Nessa perspectiva, o 
agente parte de uma base de orientação (SCHNEUWLY, 1988 apud BRONCKART, 1999) para realizar essa produção. De acordo com a perspectiva defendida por Bronckart (1999), o texto consiste em "toda unidade de produção de linguagem situada, acabada e autossuficiente (do ponto de vista da ação ou da comunicação)" (BRONCKART, 1999, p. 75).

O contexto de produção, alinhando-nos aos apontamentos de Bronckart (1999), configura-se sob diferentes fatores, os quais consistem em um conjunto de parâmetros que influenciam (de forma não mecânica) na organização do texto. Esses fatores referem-se aos mundos formais, em conformidade com a categorização de Habermas, e podem ser agrupados da seguinte maneira: (1) parâmetros referentes ao mundo físico; e (2) parâmetros referentes aos mundos social e subjetivo.

No tocante ao mundo físico, Bronckart (1999) afirma que "todo texto resulta de um comportamento verbal concreto, desenvolvido por um agente situado nas coordenadas do espaço e do tempo" (BRONCKART, 1999, p. 93). Sendo assim, resulta de um contexto físico, o qual apresenta parâmetros específicos, quais sejam: lugar de produção, que compreende o lugar físico em que o texto é produzido; o momento de produção, que se refere à extensão do tempo durante a qual o texto é produzido; o emissor, ou seja, a pessoa (ou a máquina) que produz fisicamente o texto oral ou escrito; e receptor, aquele que recebe concretamente o texto.

Já em relação aos mundos social e subjetivo (contexto sociossubjetivo), Bronckart (1999) assinala que todo texto se configura mediante a dimensão social da atividade e nas interações comunicativas que implicam esses mundos. Diante disso, o autor propõe que esse contexto subdivida-se em quatro parâmetros principais, quais sejam: o lugar social, o qual envolve o modo de interação em que o texto é produzido (escola, família, mídia, etc.); posição social do emissor, que lhe confere o estatuto de enunciador e compreende o papel social desempenhado pelo emissor na interação em curso; a posição social do receptor, que lhe confere o estatuto de destinatário e compreende o papel social desempenhado pelo receptor do texto; e objetivo(s) da interação, que se refere ao efeito que o texto pode produzir no destinatário, mediante o ponto de vista do enunciador. 
Por fim, é válido destacar que, segundo Silva (2013), inicialmente, o professor reconhece-se socialmente como professor e, em seguida, reconhece seus interlocutores; posteriormente, reconhece o lugar de produção do seu texto; por fim, utiliza-se de conhecimentos linguísticos para elaborar seu texto, levando em consideração a situação de interação específica na qual está inserido.

\section{Marcas enunciativas em questão}

Neste estudo, ancorados nos pressupostos do Interacionismo sociodiscursivo, assumimos um quadro de análise descendente", isto é, que "parte das atividades sociais às atividades de linguagem e dessas aos textos e às formas linguísticas que o compõe" (MACHADO; BRONCKART, 2006, p. 143). Conforme esta perspectiva, é necessário que se envolva as informações acerca do contexto sociointeracional de produção na análise dos textos. Essa análise se dá a partir de três níveis procedimentais: nível organizacional, nível enunciativo e nível semântico.

Este estudo apresenta reflexões alusivas ao nível enunciativo ${ }^{2}$ de análise. Além disso, tendo em vista a pergunta investigativa a que nos propomos responder, consideramos ser esse nível o mais coerente ao desenvolvimento das nossas reflexões. Nesse sentido, a análise dos dados versará sob as marcas de pessoas e modalizações presentes nos textos produzidos pelos professores.

Segundo Bronckart (1999; 2006), as modalizações englobam os julgamentos, opiniões e sentimentos no tocante ao conteúdo temático e podem ser agrupadas em quatro conjuntos, os quais conservam quatro funções específicas inspiradas na teoria dos três

\footnotetext{
${ }^{1}$ Em virtude da limitação de espaço, não detalharemos esse enquadramento teórico no presente artigo. Diante disso, recomendamos a leitura da obra referenciada.

${ }^{2}$ Segundo Lanferdini e Cristóvão (2017), "dependendo dos objetivos da pesquisa, nem todas as unidades de análise apresentadas em cada nível precisam ser contempladas” (LANFERDINI; CRISTÓVÃO, 2017, p. 1242). Diante disso, neste estudo, pautaremos a análise do corpus apenas nas marcas de pessoa e modalizações mencionadas. Para a compreensão das demais unidades de análise, recomendamos a leitura de Bronckart (1999; 2006).
} 
mundos proposta por Habermas (1987). Esses mundos constituem dimensões que, mediadas pela linguagem, referem-se tanto às representações externas/compartilhadas quanto às individuais/cognitivas dos sujeitos, consistindo em "configurações de conhecimento" construídas cumulativamente e que apresentam dimensões "transindividuais" (BRONCKART, 1999, p. 33).

Nessa perspectiva, as modalizações podem ser classificadas da seguinte forma: (1) modalizações lógicas, que se referem ao mundo objetivo e, portanto, englobam a avaliação ou julgamento “acerca do valor de verdade das proposições enunciadas, que são representadas como possíveis, prováveis, improváveis" (BRONCKART, 1999, p. 132); (2) modalizações deônticas voltam-se ao mundo social e, portanto, abarcam avaliações ou julgamentos acerca de "valores sociais, apresentando os fatos enunciados como permitidos, proibidos, necessários, desejáveis, etc” (BRONCKART, 1999, p. 132); (3) modalizações apreciativas, referem-se ao mundo subjetivo e, portanto, às avaliações ou julgamentos "mais subjetivos apresentando os fatos enunciados como bons, maus, estranhos na visão de quem avalia" (BRONCKART, 1999, p. 132); (4) modalizações pragmáticas, as quais também se voltam ao mundo subjetivo e evidenciam aspectos referentes à "responsabilidade de um personagem em relação ao processo de que é agente" (BRONCKART, 1999, p. 132), explicitando sua capacidade de ação, suas intenções e razões.

Já as marcas de pessoas, conforme apontam Machado e Bronckart (2009), oferecem pistas acerca de como o enunciador é representado através do texto. Além disso, a utilização alternada de pronomes pessoais possibilita a identificação do estatuto individual ou coletivo atribuído ao texto.

\section{Procedimentos metodológicos}

O presente estudo configura-se a partir da abordagem qualitativa de pesquisa (MINAYO, 2009). A escolha por esta abordagem é justificada pelo seu foco de investigação no que se refere ao "universo dos significados, dos motivos, das aspirações, das crenças e das atitudes" (MINAYO, 2009, p. 21) inerentes à produção humana. Em consonância com 
a abordagem em questão, este estudo apresenta natureza descritivo-interpretativista (MATTOS, 2011). A postura a ser assumida pelo pesquisador interpretativo, segundo Moreira e Caleffe (2008), é de curiosidade com relação ao ambiente ou sujeito pesquisado, ou seja, de compreensão destes.

Tendo em vista a construção de um contexto colaborativo de pesquisa, através do qual o professor se perceba como colaborador e não como sujeito avaliado, a pesquisadora pontuou, mediante o primeiro contato com o participante, que a pesquisa em questão confere especial atenção ao caráter ético dos trabalhos científicos, enquadrando-se aos Critérios $^{3}$ da Ética em Pesquisa com Seres Humanos.

Dito isto, salientamos, ainda, que foi realizado um estudo de caso (MINAYO, 1994). Entendemos que o estudo de caso oportuniza a aproximação do pesquisador com o universo pesquisado e, consequentemente, a construção do conhecimento a partir da realidade apresentada (MINAYO, 1994); contribuindo, portanto, para a observação do objeto de estudo em questão.

Visando a geração ${ }^{4}$ dos dados necessários ao desenvolvimento deste estudo e mediante a autorização do Comitê de Ética em pesquisa (CAEE 11935319.1.0000.5182), foi realizada, inicialmente, uma entrevista semiestruturada, tendo em vista a necessidade de seguirmos um plano de perguntas que se relacionam aos objetivos da pesquisa, mas que, ao mesmo tempo, permite ao entrevistado responder ao que lhe foi perguntado de maneira não padronizada (MOREIRA; CALEFFE, 2008). A entrevista foi realizada individualmente, em data, horário e local previamente escolhidos pelo participante.

Após a etapa de realização da entrevista, foram iniciadas as filmagens. Ao todo, foram filmadas oito aulas de Língua Portuguesa, destinadas, segundo o participante, ao

\footnotetext{
${ }^{3}$ Em conformidade com a Resolução no 446 de 12 de dezembro de 2012 do Conselho Nacional de Saúde e, portanto, assegurando ao participante o esclarecimento acerca de todas as informações e dúvidas que possam surgir ao longo da pesquisa, bem como a desistência da participação, caso sinta necessidade.

${ }^{4}$ É importante salientar que os dados analisados são oriundos de uma pesquisa de mestrado, desenvolvida pela presente autora e vinculada ao Programa de Pós-Graduação em Linguagem e Ensino (PPGLE/UFCG) e consiste em um recorte da pesquisa desenvolvida durante o curso.
} 
ensino do gênero textual conto fantástico. As aulas em questão, doravante sequências de ensino $^{5}$ (SE), conforme a definição proposta pelo GRAFE (SCHNEUWLY, 2009 apud SILVA, 2013), ocorreram em uma turma do terceiro ano do ensino médio, vinculada a uma Escola Cidadã Integral (ECI), situada na cidade de Campina Grande - PB. Entre as aulas filmadas, selecionamos, para este artigo, uma aula cujo foco consistiu em direcionar os alunos à produção escrita do conto.

Para a transcrição dos áudios referentes às entrevistas, bem como das falas do professor durante a interação com os alunos, foram utilizadas as normas para transcrição propostas por Preti $(1999)^{6}$, visando que haja maior clareza com relação aos dados gerados.

Com base nesses pressupostos, foi observado o dizer de um professor de Língua Portuguesa, cujo perfil professional pode ser observado no Quadro 01:

Quadro 01 - Perfil profissional e acadêmico do professor participante

\begin{tabular}{|l|c|c|c|}
\hline \multicolumn{1}{|c|}{ Formação acadêmica } & Ano de formação & $\begin{array}{c}\text { Anos de atuação } \\
\text { docente }\end{array}$ & $\begin{array}{c}\text { Experiências de } \\
\text { atuação docente }\end{array}$ \\
\hline $\begin{array}{l}\text { Graduação em Letras, com habili- } \\
\text { tação em Língua Portuguesa, pela } \\
\text { UEPB/ Campus Campina Grande. } \\
\begin{array}{l}\text { Especialização (em andamento) em } \\
\text { Ensino de Língua Portuguesa e Li- } \\
\text { teratura, na modalidade EAD. }\end{array}\end{array} \quad \begin{array}{c}\text { Graduou-se em } \\
2017 .\end{array}$ & $\begin{array}{l}6 \text { anos de atuação } \\
\text { docente. }\end{array}$ & $\begin{array}{l}\text { Rede pública de en- } \\
\text { sino, nos níveis fun- } \\
\text { damental e médio. } \\
\text { Atua em ECI há três } \\
\text { anos. }\end{array}$ \\
\hline
\end{tabular}

Fonte: corpus da pesquisa.

\footnotetext{
${ }^{5}$ Em virtude do espaço disponibilizado para este texto, salientamos em nota que as sequências de ensino consistem em um conjunto de lições ou de aulas organizadas de maneira sistemática para o estudo de um determinado objeto de ensino, do ponto de vista de diferentes dimensões (SCHNEUWLY, 2009 apud SILVA, 2013). Desse modo, uma aula consiste em uma sequência de lições, podendo ser denominada de sequência de ensino, segundo a perspectiva em questão.

${ }^{6}$ A saber: incompreensão de palavras ou de segmentos $=($ ); hipótese do que se ouviu = (hipótese); truncamento (havendo homografia, usa-se acento indicativo da tônica e/ou timbre) $=/$; entonação enfática $=$ maiúscula; prolongamento de vogal e consoante $(\operatorname{como~s,r)}=$ ::podendo aumentar para:::: ou mais; silabação = - ; interrogação $=$ ?; qualquer pausa $=\ldots ;$ comentários descritivos do transcritor $=(($ minúscula $))$; comentários que quebram a sequência temática da exposição, desvio temático = - . - ; superposição simultaneidade = ligando as minhas; indicação de que a fala foi tomada ou interrompida em determinado ponto. Não do início, por exemplo $=(. .$. citações literais ou leituras de textos, durante a gravação $=$ " “.
} 


\section{Organização dos dados e categoria de análise}

Tendo em vista a análise do dizer do professor manifestado em situação de interação com os alunos - portanto, no exercício diário da profissão -, salientamos que a aula em questão está organizada em forma de sinopse.

A sinopse, tal como é concebida pelo grupo GRAFE, consiste em um instrumento metodológico que permite a visualização sistematizada de uma sequência de ensino, ou seja, "uma descrição das principais partes, ações e principais conteúdos abordados" (SILVA-HARDMEYER, 2015). Segundo Silva-Hardmeyer (2015), tal instrumento permite a visualização dos elementos que constituem a sequência de ensino em sua relação com o objeto de ensino a partir de uma decomposição e hierarquização das atividades realizadas. Assim, a sinopse permite a visualização da organização estrutural da sequência de ensino, de modo que não seja necessária a observação da transcrição completa dessa sequência.

Por fim, apontamos que a categoria de análise considerada neste estudo se refere aos gestos didáticos fundamentais e específicos evidenciados pelos professores participantes ao longo das intervenções por eles realizadas, durante as quais direcionam os alunos à produção escrita de gêneros textuais.

\section{Gestos didáticos reveladores das orientações do professor para a produção escrita}

Ao observar a situação de interação em que o professor instrui/direciona os alunos à produção escrita dos gêneros textuais, é possível perceber um processo em que esse profissional se inscreve como sujeito produtor prescrições, ou seja, conduzindo os alunos à realização das ações traçadas por ele.

Assumindo a relevância desse processo, apresentamos, inicialmente, o encadeamento temático delineado na sequência de ensino desenvolvida pelo professor e sua relação com os gestos didáticos fundadores. A sequência de ensino em questão foi reservada, pelo professor, à produção escrita do gênero textual conto e, portanto, consistiu em uma aula durante a qual ele agiu didaticamente com o objetivo de direcionar os alunos à efetivação dessa produção. Sendo assim, 
A seguir, apresentamos, no Quadro 02, uma sinopse referente à sequência de ensino (SE) em questão, o qual ilustra como ele organiza essa sequência, considerando as relações entre o objetivo da SE, o encadeamento temático empregado, as formas sociais de trabalho, os gestos fundadores predominantes, bem como os suportes materiais utilizados:

Quadro 02 - Sinopse da SE ministrada pelo professor

\begin{tabular}{|c|c|c|c|}
\hline $\begin{array}{l}\text { Encadeamento te- } \\
\text { mático }\end{array}$ & $\begin{array}{l}\text { Formas sociais de } \\
\text { trabalho }\end{array}$ & $\begin{array}{c}\text { Gestos didáticos fundadores } \\
\text { predominantes }\end{array}$ & $\begin{array}{l}\text { Suportes } \\
\text { materiais } \\
\text { utilizados }\end{array}$ \\
\hline $\begin{array}{l}\text { 1. Retomada acerca } \\
\text { dos tipos de contos } \\
\text { literários estudados }\end{array}$ & $\begin{array}{l}\text { - Exposição oral do conteúdo; } \\
\text { - Perguntas orais feitas pelo } \\
\text { professor e respostas orais dos } \\
\text { alunos; }\end{array}$ & $\begin{array}{l}\text { - Gesto de criação de memória } \\
\text { didática (externa); } \\
\text { - Gesto de regulação; } \\
\text { - Gesto de implementação do } \\
\text { dispositivo didático. }\end{array}$ & -- \\
\hline $\begin{array}{l}\text { 2. Instrução acerca } \\
\text { de aspectos referen- } \\
\text { tes ao contexto de } \\
\text { produção e da estru- } \\
\text { tura composicional } \\
\text { do gênero }\end{array}$ & $\begin{array}{l}\text { - Exposição oral do conteúdo; } \\
\text { - Perguntas orais feitas pelo } \\
\text { professor e respostas orais dos } \\
\text { alunos; } \\
\text { - Leitura de instruções presen- } \\
\text { tes no livro didático. }\end{array}$ & $\begin{array}{l}\text { - Gesto de institucionalização; } \\
\text { - Gesto de formulação de tare- } \\
\text { fas; } \\
\text { - Gesto de regulação. }\end{array}$ & $\begin{array}{l}\text { - Livro di- } \\
\text { dático }\end{array}$ \\
\hline $\begin{array}{l}\text { 3. Solicitação da pro- } \\
\text { dução escrita }\end{array}$ & $\begin{array}{l}\text { - Exposição oral da prescrição } \\
\text { para a produção individual de } \\
\text { um conto fantástico }\end{array}$ & $\begin{array}{l}\text { - Gesto de criação de memória } \\
\text { didática (interna); } \\
\text { - Gesto de formulação de tare- } \\
\text { fas. }\end{array}$ & -- \\
\hline
\end{tabular}

Fonte: corpus da pesquisa.

Através do quadro em questão, observamos, inicialmente, que o objetivo da SE ministrada pelo professor volta-se ao direcionamento dado por ele para que os alunos produzam o gênero textual conto.

O encadeamento 01 marca o início da SE, quando o professor retoma os tipos de conto por meio da exposição oral do conteúdo e de perguntas direcionadas aos alunos. Nesse momento, o professor aciona os gestos didáticos de criação de memória didática, regulação e implementação do dispositivo didático em função do objetivo da sequência (orientar os alunos a produzir um conto fantástico). Esses gestos se desdobram em gestos específicos e podem ser identificados a partir do dizer do professor nos minutos iniciais da SE. O Quadro 03, a seguir, sintetiza esses gestos: 
Quadro 03 - Gestos didáticos referentes ao encadeamento 01 Gestos didáticos específicos do ponto de vista da criação de memória didática

- Retomada conteúdos estudados anteriormente.

Gestos didáticos específicos do ponto de vista da regulação

- Invalidação das respostas dos alunos reformulando a resposta; - Invalidação das respostas dos alunos através do advérbio de negação.

Gestos didáticos específicos do ponto de vista da presentificação

Introdução da atividade a ser realizada durante a aula.

Fonte: corpus da pesquisa.

O primeiro gesto a partir do qual aciona a memória didática dos alunos é realizado quando o professor a sequência de ensino em questão, retomando o nome dos tipos de conto estudados anteriormente. Para compreendermos esse gesto, apresentamos o Excerto 01:

\section{Excerto 01:}

Professor: Gente, é.. trabalhamos os tipos, trabalhamos contos, os tipos de conto.. vocês lembram quais foram os tipos? (professora em frente à turma)

Alunos: Romântico, de humor, erótico...

Professor: Erótico, de humor, certo? Que mais? Realista, de terror, erótico..

Aluno: Fantástico.

Professor: Fantástico (professora balançando a cabeça e apontando para os alunos demonstrando concordar com o que o aluno está afirmando). E tem os contos infantis, né? Quais foram os contos que a gente viu em vídeo, que a gente assistiu? [...]

Alunos: De terror...

Professor: De terror, de humor, fantástico...

Alunos: De humor.

Professor: Não, aquele é realista (professora apontando para o aluno demonstrando não concordar com o que está sendo dito por ele). A gente leu o de humor, o de Lucicleide e o erótico foi a leitura que a gente fez, a do girassol (fazendo referência a personagens dos contos lidos anteriormente) [...] Hoje ficou dito que, já que várias quartas-feiras a gente não teve aula, teve sempre algo atrapalhando para não ter (aula), aí ficou da gente fazer a produção. Ou seja, VOCÊS, protagonistas, fazerem a produção de vocês, ou seja, produzir um conto. (grifo nosso)

Através do primeiro gesto (retomar conteúdos estudados anteriormente), o professor faz com que os alunos relembrem os tipos de conto estudados em aulas anteriores para que, na presente aula, possam utilizar os conteúdos mencionados ao que será proposto como tarefa. Desse modo, o professor intervém realizando um movimento de criação de 
memória didática externa (uma vez que retoma conteúdos referentes a outra sequência de ensino), visando estabelecer uma relação entre o que está sendo ensinado e o que foi ensinado anteriormente, de modo que haja a reconstituição de um trabalho fragmentado.

Do ponto de vista enunciativo (BRONCKART, 1999, 2008), observou-se que esse gesto é demonstrado através de comandos orais direcionadas aos alunos (Vocês lembram quais foram os tipos? / Quais foram os contos que a gente viu em video, que a gente assistiu?), a partir das quais se observa o uso de diferentes marcas de pessoa "vocês" e "a gente"; em conjunto com verbos flexionados no pretérito "trabalhamos", "a gente viu" e "a gente assistiu".

O segundo e terceiro gestos (Invalidar e/ou validar as respostas dos alunos) são acionados logo após o gesto de criação de memória didática e visam regular e avaliar os conhecimentos apontados pelos alunos, validando-os ou não no momento da interação em questão.

Ao repetir a fala do aluno e, concomitantemente, demonstrar concordar com ele através de movimentos corporais, o professor valida o conhecimento apontado por um aluno. Por outro lado, a resposta de outro aluno é negada através do advérbio de negação “não”, seguido da reformulação da resposta e, concomitantemente, de movimentos corporais que reforçam essa negação. Tais gestos sinalizam a intenção do professor de verificar se os alunos de fato se apropriaram dos conteúdos em questão para que possam utilizá-los no momento da produção escrita. Desse modo, o professor também articula o conteúdo estudado em aulas anteriores à atividade a ser desenvolvida na presente aula.

A partir do excerto 01, também é possível identificar a implementação do dispositivo didático a partir do gesto específico de introdução da atividade a ser realizada na SE atual. Linguisticamente, esse gesto é marcado por meio do dêitico temporal "hoje", bem como pelos verbos que expressam ação realizada anteriormente "ficou dito" e verbos que expressam processo a ser realizado durante a aula atual, como "fazer" (boje ficou dito que... ficou da gente fazer a produção). Nesse momento, o professor se posiciona em frente à turma. Desse modo, o docente assume sua posição de agente que prescreve essa ação e busca motivar os alunos a realizá-la ao apresentá-los como protagonistas da atividade proposta (VOCÊS, protagonistas, fazerem a producão de vocês, ou seja, produð̣ir um conto). 
Conforme apontado, tal encadeamento ocorre nos minutos iniciais da aula e logo se desdobra para o encadeamento 02 (delimitação dos aspectos referentes ao contexto de produção e da estrutura composicional do gênero conto fantástico). Assim como observado no encadeamento 01, no encadeamento 02 o professor realiza suas ações por meio da exposição oral do conteúdo e de perguntas orais dirigidas aos alunos. Além disso, realiza a leitura de instruções presentes no livro didático disponibilizado pela escola, intercalando essa leitura às suas exposições, uma vez que, no momento da leitura, apenas o professor tinha acesso ao livro didático. Sendo assim, os alunos tinham acesso apenas à exposição feita pelo professor.

Nesse sentido, as instruções dadas pelo professor e, concomitantemente, os gestos acionados ao longo do encadeamento 02 estão inerentes a esse cenário. O Quadro 04, a seguir, sintetiza esses gestos:

Quadro 04 - Gestos didáticos referentes ao encadeamento 02

Gestos didáticos específicos do ponto de vista da focalização

- Introduzir a sequência de instruções para a produção do conto;

- Instruções acerca de elementos e/ou características que os alunos devem contemplar na produção do conto: (1) atentar para o público-alvo ao qual o conto será direcionado; (2) escolher o tipo de conto a ser escrito; (3) atentar para as características do contexto de produção do conto; (4) atentar para as características estruturais do conto.

Gestos didáticos específicos do ponto de vista da regulação

- Validação do conhecimento apresentado pelo aluno.

Fonte: corpus da pesquisa.

O primeiro gesto do ponto de vista da focalização foi realizado logo após o gesto de criação de memória didática e sinaliza uma articulação entre esses. Isso pode ser percebido uma vez que, ao longo do encadeamento 01 , o professor realizou a retomada dos tipos de conto estudados em aulas anteriores e, partindo disso, começou a delinear a solicitação da produção escrita, conforme ilustrado no Excerto 02:

\section{Excerto 02:}

Professor: Então, antes de vocês escreverem, o que é que vocês precisam entender e compreender para produzir o conto de vocês? (professora em frente à turma) [...] Vocês que vão escolher o tipo, se é fantástico, se é realista, se é erótico, se é.. o que mais? Se é um conto infantil ou se é um conto humorístico.. então vocês vão escolher. Certo? Fica a critério. Porque 
uma pessoa pode ter habilidade de produzir um conto humorístico e outra não ter, né? Então vocês vão escolher o tipo que vocês verem que se adequa. (grifo nosso)

Inicialmente, através do Excerto 02, é possível perceber que o professor introduz a prescrição referente à produção escrita, chamando a atenção dos alunos para o que será solicitado. Esse gesto é acionado por meio de consignas orais realizadas pelo professor (antes de vocês escreverem, o que é que vocês precisam entender e compreender para produzir o conto de vocês?), nas quais observamos a utilização da modalização deôntica "precisam", indicando uma regra que, necessariamente, deve ser seguida pelos alunos para que possam produzir o conto. Ao realizar esse questionamento, o professor não busca interagir com os alunos, aguardando ou incitando-os a responderem o que está sendo questionado, o que evidencia o caráter prescritivo do gesto em questão.

Após isto, compreendemos que é acionado o gesto de focalização, uma vez que o professor apresenta um comando no intuito de instruir os alunos a escolherem o tipo de conto a ser escrito por eles (Vocês que vão escolher o tipo, se é fantástico, se é realista, se é erótico... / Então vocês vão escolher o tipo que vocês verem que se adequa).

Esses gestos são marcados linguisticamente pela utilização de marcas de pessoa e formas verbais que indicam a ação a ser realizada pelos agentes. A recorrência da marca de pessoa "vocês" sinaliza o grau de implicação do professor em relação ao que está sendo dito. Ou seja, enquanto enunciador do texto, o docente se distancia do que está sendo dito, evidenciando sua posição em relação aos demais actantes envolvidos na interação; os alunos. Além disso, também são utilizadas formas verbais como o verbo ir, flexionado no imperativo afirmativo; em conjunto com o verbo escolher (vão escolher), indicando a ação a ser realizada; e a explicitação do conteúdo escolar abordado durante a SE, o conto fantástico. Dessa forma, o professor se coloca como agente que prescreve a ação a ser realizada pelos alunos.

Além desse gesto, durante o encadeamento 02 , o docente aciona o gesto de instruir a atentar para as características referentes ao contexto de produção do conto. A respeito 
dessas características, ele destaca os possíveis receptores e o possível local de circulação do texto a ser escrito pelos alunos, conforme ilustrado no Excerto 03:

\section{Excerto 03:}

Professor: Primeiro, planeje seu conto (professora lendo o livro didático em frente aos alunos). Que você vai produzir tendo em vista o quê? O público-alvo (lendo). ou seja, pra quem você vai escrever o texto. É pra adolescente? Então você vai direcionar, você vai produzir para aquela classe, ou seja, pra o adolescente ler, por exemplo, né? Jovens e adultos que se interessam por literatura fantástica (lendo). Certo? Então se você vai produzir pra o mesmo público que você, então vocês vão o quê? [...] Faça de conta que vocês vão produzir pra outra turma, por exemplo, ou pra apresentar pra escola, por exemplo, certo? Só um exemplo. O que mais? (professora em frente à turma). (grifo nosso)

Através do gesto de instruir a atentar para as características referentes ao contexto de produção do conto, o professor focaliza o público-alvo ao qual o texto escrito pelo aluno deve ser direcionado (O público-alvo (lendo)... ou seja, pra quem você vai escrever o texto lendo). Com isso, é delimitada uma dimensão a ser abordada pelos estudantes na produção do conto.

Assim, observa-se que o professor age didaticamente orientando os alunos no que se refere a um conhecimento que deve ser mobilizado no momento da produção escrita. A delimitação do público-alvo ao qual o conto deve ser destinado é relevante e se alinha parcialmente aos apontamentos de Bronckart (2006), uma vez que se volta a um dos parâmetros referentes ao contexto sociossubjetivo que influencia na organização textual, nesse caso, o destinatário do texto.

Todavia, entendemos que outros aspectos, ainda corroborando as afirmações de Bronckart (2006), também podem contribuir para que o aluno possa realizar uma produção textual mais efetiva; tais como: a compreensão da posição social do emissor, englobando o papel social desempenhado pelo emissor na interação em questão; da posição social do receptor, ou seja, o papel social desempenhado pelo receptor do texto; e dos objetivo(s) da interação, englobando os possíveis efeitos esperados a partir da produção de um texto, tendo em vista destinatários específicos. 
Nesse sentido, enquanto profissional que age didaticamente visando fazer com que os alunos realizem a produção escrita, é relevante que o professor evidencie esses aspectos nesse momento de direcionamento.

Ainda no que se refere ao Excerto 03, é possível perceber a reincidência da marca de pessoa "você/vocês", direcionada aos alunos; quanto dos verbos de ação e de processo (vai produzir/vai direcionar/vão produzir). Com isso, observa-se que o participante se coloca como agente que prescreve a atividade a ser realizada pelos alunos. Em outras palavras, o professor se coloca como emissor da interação em curso, cabendo ao aluno o estatuto de destinatário.

Para prescrever a ação de atentar para as características estruturais do conto, o professor articula sua exposição oral ao que está prescrito no livro didático, ou seja, realiza a leitura dos aspectos apresentados no livro, destaca e explica oralmente alguns dos aspectos lidos. Observemos, a seguir, o trecho do livro didático utilizado pelo professor (como demonstra a Figura 01, a seguir), bem como o Excerto 04 (apresentado logo após a Figura 01), que ilustram essa articulação:

Figura 01 - Instruções presentes no livro didático utilizado por P1

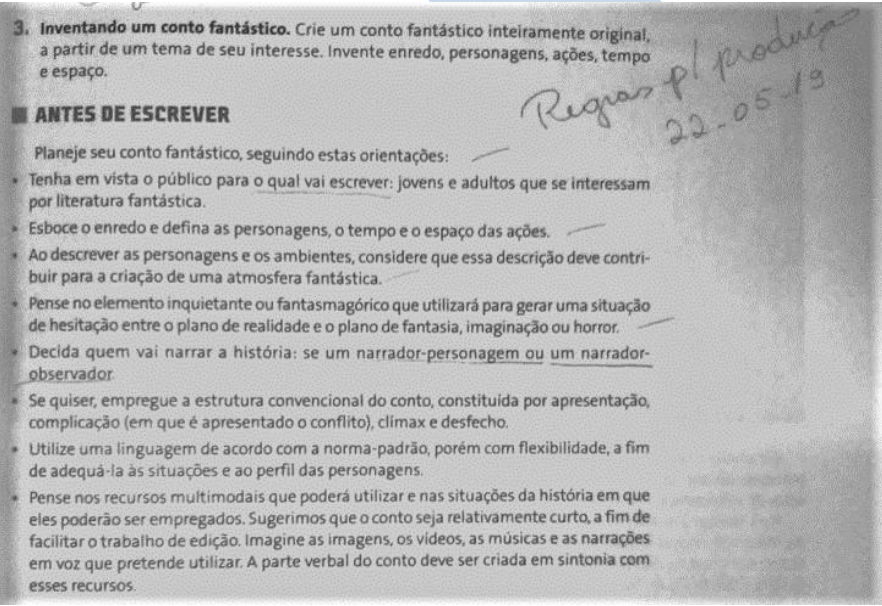

Fonte: corpus da pesquisa. 


\section{Excerto 04}

Professor: Esboce o enredo e defina as personagens, o tempo e o espaço das ações (professora lendo o livro didático e em frente à turma). Então vocês fazem o quê? Um planejamento mental e vocês vão.. vai ter quantos personagens no meu conto? Dois? Três? Né? Tem que ter pouquinhos, tem que ter pouquinhos, até quatro, cinco, no máximo esses personagens. Certo? Então vocês precisam falar sobre eles e até porque fica mais fácil, né? De escrever, do que você botar 30 personagens, aí não vai dar tempo... [...] Linguagem.. qual seria a linguagem que vocês vão utilizar? Agora, lembrando, a linguagem que vocês vão utilizar não vai ser aquela que vocês usam coloquialmente não, tá? Tenham cuidado com isso.. pra não colocarem pra mim fazer, pra mim comer.. pra mim.. enfim.. esse tipo de coisa a gente deve evitar, tá certo? [...]

Aluno: Professora, só pode linguagem formal?

Professor: Você pode utilizar uma linguagem informal... depende do que você vai colocar no seu texto. [...] Utilize uma linguagem de acordo com a norma padrão, porém com flexibilidade, afim de adequá-la às situações e ao perfil das personagens. (grifo nosso)

Com a observação da Figura 01 e do Excerto 04, observa-se que o professor seleciona os trechos a serem destacados para os alunos e, concomitantemente, reelabora as instruções presentes no livro didático. Assim, o professor age levando em consideração a situação de interação em que se insere, utilizando-se de conhecimentos linguístico-discursivos para a elaboração do seu texto e, consequentemente, realizando a mediação da situação de aprendizagem, tendo em vista os objetivos pretendidos.

Também é possível perceber o caráter prescritivo inerente a essa situação de interação através dos seguintes elementos: os verbos flexionados no imperativo afirmativo e, por sua vez, a posição de agente da prescrição assumida por ele (Esboce o enredo e defina as personagens, o tempo e o espaço das ações (lendo)/ Vai ter quantos personagens no meu conto? Dois? Três? Né? Tem que ter pouquinhos, tem que ter pouquinhos/ Então vocês precisam falar sobre eles).

Ao realizar esse destaque, o professor utiliza algumas marcas linguísticas que reforçam o gesto de prescrever as ações a serem realizadas pelos alunos, como demonstrado pela utilização da modalização deôntica expressa pelas formas verbais “tem que ter" e "precisa", delimitando conteúdos que estão em conformidade com regras e/ou normas estabelecidas para a produção do conto fantástico.

Desse modo, observa-se que o professor realiza uma sequência de gestos que sinalizam um caráter instrucional. 
Os gestos em questão - focalização e prescrição da ação de atentar para características estruturais do conto - também são percebidos quando o professor destaca outra regra que deve ser seguida pelos alunos, segundo suas representações: a utilização da norma padrão da língua (a linguagem que vocês vão utilizar não vai ser aquela que vocês usam coloquialmente não/Você vai utilizar uma linguagem formal). Essa regra é reforçada pelo uso da marca de pessoa "a gente" e da modalização pragmática expressa pela forma verbal "deve evitar" (esse tipo de coisa a gente deve evitar), revelando o julgamento do professor quanto ao uso da norma coloquial da língua.

Todavia, após um questionamento feito por um aluno, o professor realiza o gesto de validação do conhecimento apresentado por ele. Esse gesto pode ser observado a partir da reformulação do próprio dizer, realizada pelo professor (Utilize uma linguagem de acordo com a norma padrão, porém com flexibilidade, afim de adequá-la às situações e ao perfil das personagens).

Ao final da sequência de ensino, no que se refere ao encadeamento 03, o professor realiza a solicitação da produção escrita através da exposição oral do que deve ser escrito pelos alunos. Para tanto, aciona o gesto de formulação de tarefas, conforme apresentado no Quadro 05, a seguir:

Quadro 05 - Gestos didáticos fundadores referentes ao encadeamento 03

Gestos didáticos específicos do ponto de vista da criação de memória didática (interna)

- Retomada de conteúdo visto durante a aula atual

Gestos didáticos específicos do ponto de vista da formulação de tarefas

- Prescrição da ação de produzir o conto

Fonte: corpus da pesquisa.

Para formular a tarefa atual, o professor aciona o gesto específico de prescrever para os alunos a ação de produzir o conto. Tal gesto pode ser observado no Excerto 05, a seguir:

\section{Excerto 05}

Professor: Certo, gente, então isso aí são os pontos que vocês devem ter base pra produção do conto de vocês. Vocês vão fazer numa folhinha de caderno bonitinha pra me entregar, depois que produzir e eu vou fazer a correção (professora em frente à turma). (grifo nosso) 
Através desse gesto, o docente reforça o objetivo da sequência de ensino e, concomitantemente, estabelece uma relação com os demais encadeamentos e gestos evidenciados ao logo da sequência, acionando o gesto de criação de memória didática interna (então isso ai são os pontos que vocês devem ter base pra producão do conto de vocês). Para tanto, o professor faz uso da modalização deôntica expressa pelas formas verbais “devem ter", tendo em vista o objetivo da interação. Desse modo, o professor mobiliza recursos linguísticos considerando os efeitos que seu texto pode produzir em relação aos destinatários.

Por fim, é acionado o gesto de formulação de tarefa, de modo que a solicitação para a produção do conto é marcada pela utilização do verbo ir, flexionado no imperativo afirmativo, em conjunto com o verbo escolher, (Vocês vão fazer numa folhinha de caderno), visando orientar as ações dos alunos no tocante à execução da produção escrita, conferindo-lhe, portanto, o papel de enunciador e aos alunos o papel de destinatários das suas ações de linguagem.

\section{Considerações finais}

No presente estudo, nos propomos a identificar e interpretar os gestos didáticos reveladas no dizer do professor, em situação de interação com os alunos.

A partir da leitura dos dados construídos, bem como das sustentações teóricas apresentadas, é possível afirmar que a identificação e interpretação dos gestos didáticos fundadores e específicos presentes na sequência de ensino realizada pelo professor, bem como da relação entre esses gestos e o encadeamento de ações efetivado; permitiu que compreendêssemos especificidades que emergem no momento da interação entre professor e aluno cujo objetivo é orientar os alunos à produção escrita.

Além disso, observou-se que a utilização de formas verbais, modalizações, marcas de pessoa, consignas orais e aspectos extralinguísticos contribui para a realização e compreensão das ações reveladas pelo professor mediante o contexto de interação no qual está inserido. As especificidades mencionadas também sinalizam que os gestos acionados foram perpassados pelo objetivo do professor de instruir os alunos e prescrever a produção escrita do conto. 
Com isso, compreendemos a relevância da promoção de pesquisas que visem, em colaboração com o professor, compreender o processo de orientações docentes para a produção escrita sob o viés dos gestos didáticos, objetivando traçar, a partir do contexto de interação específico em que esse profissional está inserido, novas estratégias de desenvolvimento desse processo. Nesse sentido, partindo da compreensão acerca das especificidades referentes ao contexto de ensino em que o professor está inserido, defendemos que é possível contribuir para que o professor possa realizar um trabalho mais efetivo no tocante ao ensino de escrita.

\title{
DIDACTIC GESTURES REVEALED IN THE PORTUGUESE LANGUAGE TEACHER'S SPEECH IN A WRITING-TEACHING SITUATION
}

\begin{abstract}
In this paper, a case study is presented (MINAYO, 1994) which objective is to identify and interpret the didactic gestures evidenced in the Portuguese language teacher's speech during the interventions that aimed to direct students to the written production of the fantastic tale text genre. Therefore, this article relies on the discussions proposed by Sociodiscursive Interactionism, regarding to the conditions of the text production and the enunciative marks asserted by Bronckart (1999). Then, based on the Didactics of Languages assumptions, the notion of didactic gestures is discussed. In this sense, this article is a research based on the qualitative paradigm of science (MINAYO, 2009), with ethnographic basis (MATTOS, 2011). The generation of the data took place in two stages: (1) semi-structured interview; (2) filming of a class taught by the participant, in a class of the third year of high school from an Integral Citizen School located in the city of Campina Grande - PB. Based on this study, it was possible to observe that, during the class in question, the teacher triggered the gestures of creating didactic memory (internal and external), regulation, implementation of the didactic device, institutionalization and task formulation; which unfolded in specific didactic gestures. These gestures signal the management performed by the teacher with regard to the guidelines for the written production of the story, in view of the interaction context in which the fantastic tale is inserted.
\end{abstract}

KEYWORDS: Teaching of writing; Didactic gestures; Guidelines for producing texts.

\section{REFERÊNCIAS}

BRONCKART, J. P. Atividade de linguagem, textos e discursos. Por um interacionismo sociodiscursivo. Trad. Anna Rachel Machado e Péricles Cunha, São Paulo, Educ, 1999. . Atividade de linguagem, discurso e desenvolvimento humano. Campinas: Mercado de Letras, 2006.

GOMES-SANTOS, S. N. ; JORDÃO, H. G. . O texto no trabalho de alfabetização: aspectos didáticos e interacionais de uma atividade escolar. In: BARROS, E.M.D.; CORDEIRO, 
G.S.; GONÇALVES, A.V. (Orgs.). Letramentos, objetos e instrumentos de ensino: gêneros textuais, sequências e gestos didáticos. $1^{\text {a }}$ ed. Campinas, SP: Pontes Editores, 2017. p. 59-89.

LANFERDINI, P. A. F.; CRISTOVAO, V. L. L. O agir docente revelado no trabalho de planejamento e produção de uma sequência didática: contribuições para a construção de uma semiologia do agir. DELTA [online], v. 33, n. 4, p. 1235-1269, 2017.

MACHADO, A. R.; BRONCKART, J. P. (Re-)configurações do trabalho do professor construídas nos e pelos textos: a perspectiva metodológica do Grupo ALTER-LAEL. In: MACHADO, A. R e colaboradores; ABREU-TARDELLI, L.S.; CRISTÓVÃO, V.L.L. (Orgs); posfácio Joaquim Dolz. Linguagem e educação: o trabalho do professor em uma nova perspectiva. Campinas: Mercado de Letras, 2009, p. 31-77.

MATTOS, C.L.G. A abordagem etnográfica na investigação científica. In MATTOS, C.L.G.; CASTRO, P. A., (Orgs.). Etnografia e educação: conceitos e usos [online]. Campina Grande: EDUEPB, 2011. p. 49-83. ISBN 978-85-7879-190-2.

MESSIAS, C., DOLZ-MESTRE, J. As noções de gestos e de agir didático para a formação de professores de linguas: interfaces do trabalho docente. São Paulo: Cadernos Cenpec, vol. 5, n. 1, p. 44-67, jan./jun. 2015.

MINAYO, M. C. S. O desafio da pesquisa social. In: Deslandes, S.F.; GOMES, R.; MINAYO, M.C.S. (Orgs.) Pesquisa social: teoria, método e criatividade. 17. ed. Petrópolis: Vozes, 2009. p. 9-29.

MOREIRA, H.; CALEFFE, L. G. Metodologia da pesquisa para o professor pesquisador. 2. ed. Rio de Janeiro: Lamparina, 2008.

NASCIMENTO; E. L.; BRUN, E. P. Transposição didática e gestos profissionais de ensinar: a construção do objeto de ensino pelo professor de língua portuguesa. In: BARROS, E. M. D. de; CORDEIRO, G. S.; GONÇALVES, A. V. (Orgs.) Gestos didáticos para ensinar a língua: agir docente e gêneros textuais. Campinas: Pontes, 2017. p. 47-81.

NASCIMENTO, E. L. A dupla semiotização dos objetos de ensino-aprendizagem: dos gestos didáticos fundadores aos gestos didáticos específicos. Signum: Estudos Linguísticos, Londrina, n. 14/1, p. 421-445, jun. 2011.

PRETI D. Apresentação. In: PRETI, D. (Org). Análise de textos orais. 4a . ed. São Paulo: Humanitas Publicações - FFLCH/USP - (Projetos Paralelos. V.2), 1999, p. 7-12.

SILVA, A. A. P.; SILVA, C. M. R. A pesquisa, uma necessidade para os professores de lingua. Entrevista com o prof. Dr. Joaquim Dolz. Revista NUPEM (Online), v. 4, n. 7, p. 11-22, ago./dez. 2012.

SILVA, C. M. O agir didático do professor de língua portuguesa e sua reconfiguração em textos de autoconfrontação. 2013. 384 f. Tese (Doutorado em Linguística Aplicada e Estudos da Linguagem) - Pontifícia Universidade Católica de São Paulo, São Paulo, 2013. 
SILVA-HARDMEYER, C. Gestos e agir didático do professor de lingua portuguesa: entre o gênero textual e a gramática. Revista L@el em (Dis)curso. v. 7, n. 121-157, 2015.

Recebido em: 09/05/2020.

Aprovado em: 26/05/2020. 